Article

\title{
Eco-Labeled Seafood: Determinants for (Blue) Green Consumption
}

\author{
Malin Jonell ${ }^{1,2, *}$, Beatrice Crona ${ }^{3,4}$, Kelsey Brown ${ }^{1}$, Patrik Rönnbäck ${ }^{2}$ and Max Troell ${ }^{3,5}$ \\ 1 Department of Ecology, Environment and Plant Sciences, Stockholm University, SE-106 91 Stockholm, \\ Sweden; kelseyasherb@gmail.com \\ 2 Department of Earth Sciences, Uppsala University, Villav. 2, SE-752 36 Uppsala, Sweden; \\ patrik.ronnback@geo.uu.se \\ 3 Stockholm Resilience Centre, Stockholm University, SE-106 91 Stockholm, Sweden; \\ beatrice.crona@su.se (B.C.); max.troell@beijer.kva.se (M.T.) \\ 4 Royal Swedish Academy of Sciences, Box 50005, SE-104 05 Stockholm, Sweden \\ 5 Beijer Institute, Royal Swedish Academy of Sciences, Box 50005, SE-104 05 Stockholm, Sweden \\ * Correspondence: malin.jonell@geo.uu.se or malin.jonell@gmail.com; Tel.: +46-70-4877992 \\ Academic Editor: Marc A. Rosen \\ Received: 23 July 2016; Accepted: 30 August 2016; Published: 2 September 2016
}

\begin{abstract}
Eco-certification has become an increasingly popular market-based tool in the endeavor to reduce negative environmental impacts from fisheries and aquaculture. In this study, we aimed at investigating which psychological consumer characteristics influence demand for eco-labeled seafood by correlating consumers' stated purchasing of eco-labeled seafood to nine variables: environmental knowledge regarding seafood production, familiarity with eco-labels, subjective knowledge, pro-environmental self-identification, sense of personal responsibility, concern for negative environmental impacts from seafood production, perceived consumer effectiveness, gender and education. Questionnaires were distributed to consumers in Stockholm, Sweden, and the data were tested with multiple regression analysis using linear modeling and model averaging $(n=371)$. Two variables were the best predictors of stated purchasing of eco-labeled seafood: (i) recognition and understanding of eco-labels for seafood (Marine Stewardship Council, Fish for Life, Aquaculture Stewardship Council and KRAV); and (ii) concern for negative environmental impacts associated with seafood production. Meanwhile, consumer environmental knowledge was a weaker predictor. Results from this study suggest that strengthening the emotional component of consumer decision-making and improving the level of consumer familiarity with seafood eco-labels could stimulate more pro-environmental seafood consumption.
\end{abstract}

Keywords: eco-labeling; certification; seafood; consumer behavior; Sweden

\section{Introduction}

Capture fisheries and aquaculture (farming of aquatic organisms, including animals and plants) can, just as other food production sectors, negatively impact aquatic and terrestrial ecosystems, e.g., through overfishing (fisheries for human consumption and for aquatic oils and proteins used in animal feeds), eutrophication due to the release of excess nutrients, feed production and the spread of invasive species and diseases [1-3]. Such adverse environmental and social impacts have together with a perceived failure of regulatory mechanisms (e.g., implementation of national legislation and codes of conduct to improve the sector) largely driven the development of seafood eco-certification programs. During the last decade, the number of eco-labeled seafood products available on European and North American markets has increased substantially [4]. While there has been a rapid development of certification initiatives for seafood, the eco-certified share of global seafood production remains 
small $[4,5]$. A further increase is conceivably dependent on consumers' demand for labeled products, and consumers are therefore key actors in market-based efforts aiming at improving the performance of the seafood sector.

As the number of certification schemes for seafood is growing, so is the body of literature analyzing consumers' perceptions of, and willingness to pay for, eco-labeled seafood. The majority of studies have focused on capture fisheries and only a few on farmed seafood [6]. Earlier work has either: (a) applied an experimental approach using contingent valuation to estimate consumers' willingness to pay for eco-labeled seafood [7-10]; (b) examined consumers' attitudes towards eco-labeling of seafood [11-13]; (c) more generally explored the perceived importance of sustainability and ethics related to seafood [14,15]; or (d) used market data to investigate whether there is a price premium for eco-certified seafood $[16,17]$. While this work has substantially increased our understanding of what factors predict willingness to purchase sustainable seafood, to our knowledge, no study has yet investigated how consumers' self-reported purchasing behavior of eco-labeled seafood is correlated with environmental knowledge and other internal factors expected to predict pro-environmental consumption. This study addresses this gap or knowledge deficit using consumer data from Stockholm, Sweden. First, we investigated the level of consumer knowledge regarding environmental impacts of seafood production and production practices (both aquaculture and capture fisheries) and the main sources of information used by consumers. Second, we assessed the relative importance of key personal characteristics predicted to be essential for pro-environmental consumer behavior to identify the most crucial internal barriers for increased demand for eco-labeled seafood. Sweden is a particularly interesting case since the market for eco-labeled food can be considered relatively mature $[18,19]$ (the sales value of organic food reached more than seven percent by 2015 [20]), and Swedish consumers generally show positive attitudes towards eco-labeled food products [21].

\section{Methods}

The Methods section begins with a brief introduction to the pro-environmental behavior literature (Section 2.1) followed by a presentation of the theoretical framework used for this study (Section 2.2) and the methodological approach for gathering and interpreting data (Sections 2.3-2.5).

\subsection{Theoretical Background}

A number of theoretical frameworks have been developed to identify internal (e.g., awareness and attitudes) and external (e.g., price and availability) drivers that positively correlate with pro-environmental behavior, such as consumption of eco-labeled food. External predictors relevant for determining the extent of pro-environmental consumer behavior include affordability and the availability of sustainable/eco-labeled goods [22]. Internal factors are more multi-faceted. Empirical work has shown that consumer awareness can be a relevant determinant for predicting purchasing decisions and that there appears to be a link between environmental knowledge and tendency to purchase eco-labeled food [23-26]. Earlier research has also indicated potentially stronger links between consumers' subjective knowledge (thus, their perceived level of knowledge) and pro-environmental consumer behavior than between (actual) knowledge and behavior [23,27]. Related to this are other internal factors, such as consumers' pro-environmental self-identification [28], concern for negative environmental impacts $[29,30]$ and perceived consumer effectiveness (PCE). The latter is defined as the extent to which the individual believes (s)he can contribute to better production practices by choosing an eco-labeled alternative [23,31-33]. While previous work has shown that certain socio-demographic characteristics seem to be correlated with pro-environmental behavior [34], e.g., that women and well-educated people are more prone to green consumption [35], results between studies are inconsistent, suggesting that demographic variables may be a comparatively poor predictor of pro-environmental conduct [36]. 


\subsection{Theoretical Framework Guiding the Study}

The theoretical framework guiding this study draws on existing theory regarding internal factors affecting pro-environmental consumer behavior. Specifically, we modify the model proposed by Kollmuss and Agyeman (2002) [37] to investigate the role of consumers' knowledge pertaining to seafood production and other internal factors (Figure 1). In the original model, three broad categories of internal variables, namely knowledge, feelings/fear/emotional involvement and values/attitudes, as well as external factors are predicted to influence pro-environmental behavior. In our modified framework, the focus was solely on the cognitive (knowledge of issues and action strategies) and emotional elements. Subjective knowledge, pro-environmental self-identification, personal responsibility and PCE were factors added to the original model. The model therefore predicts that pro-environmental behavior is determined by external and internal factors, the latter including PCE, environmental knowledge and awareness of action strategies, environmental concern (i.e., emotional involvement), pro-environmental self-identification, as well as values, attitudes and beliefs.

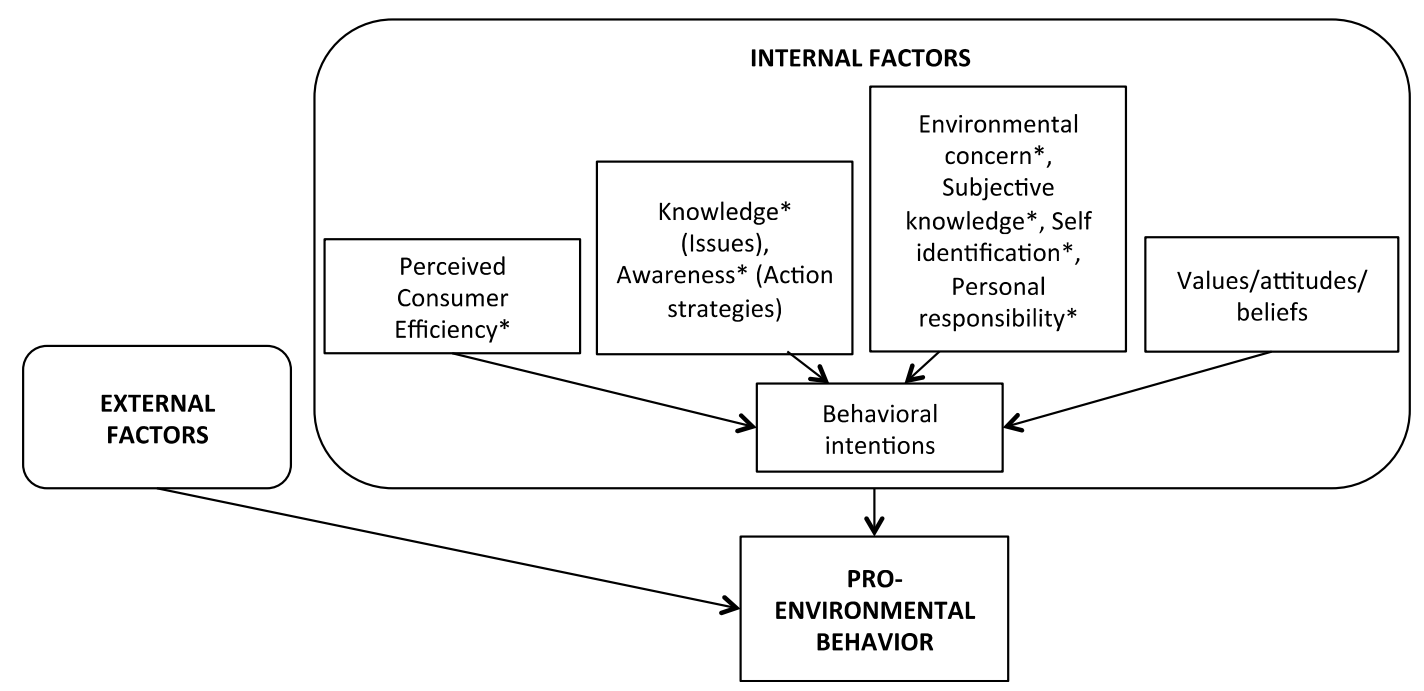

Figure 1. Theoretical framework used in this study. The focus was particularly on the following factors: perceived consumer effectiveness, knowledge of issues, awareness of seafood eco-labels, environmental concern, subjective knowledge, self-identification and personal responsibility (independent factors measured in this study marked with *). Model adapted from Kollmuss and Agyeman (2002) [37].

The measure for pro-environmental behavior used in this study is 'stated purchasing of eco-labeled seafood', thus the extent individuals report that they buy labeled alternatives. Self-reported behavior has traditionally been used as a measure for 'habit' and directly influences future conduct [38], and we therefore assume it to be closely related to pro-environmental behavior. In other words, people stating that they purchase seafood to a given extent intend to do so also in the future. Earlier work has pointed out that individuals participating in research measuring stated behavior or preferences sometimes tend to overestimate the extent they behave pro-environmentally, e.g., are willing to pay for an eco-labeled product [39]. However, others suggest that the size of this intention-behavior gap (if it exists) depends in large part on, e.g., how questions are posed [40] and the level of consumer objective knowledge [41]. In short, even though there may be a (slight) gap between intention and actual conduct, empirical work shows that a link between stated and actual behavior exist, while not always as strong as stated by respondents (e.g., [42]). The independent factors investigated here (marked with an asterisk in Figure 1) are presented in Table 1, which elaborates on the postulated relation to stated purchasing of eco-labeled seafood (SPES) and introduces the variables measured in the survey instrument used in this study: knowledge of environmental impacts from seafood production system, awareness of seafood eco-labels, worry about environmental impacts linked to seafood production systems, PCE, gender and level of education. 
Table 1. Explanatory variables expected to affect the extent to which consumers state that they choose eco-labeled seafood when available. The association with the terms used in the theoretical framework in Figure 1 is presented in the 'theoretical framework' column, and 'variable measured' indicates how the factor was captured in the questionnaire.

\begin{tabular}{|c|c|c|c|c|}
\hline $\begin{array}{l}\text { Theoretical } \\
\text { Framework }\end{array}$ & $\begin{array}{c}\text { Factors } \\
\text { Investigated }\end{array}$ & $\begin{array}{c}\text { Postulated Relation to Stated } \\
\text { Purchasing of Eco-Labeled } \\
\text { Seafood (SPES) } \\
\end{array}$ & References & Variable Measured \\
\hline Knowledge (issues) & $\begin{array}{l}\text { Environmental } \\
\text { knowledge } \\
\text { (obj. knowledge) }\end{array}$ & $\begin{array}{l}\text { Knowledge of environmental } \\
\text { impacts of seafood production } \\
\text { is positively correlated } \\
\text { with SPES }\end{array}$ & {$[43,44]$} & $\begin{array}{l}\text { Knowledge pertaining to } \\
\text { environmental impacts of } \\
\text { seafood production }\end{array}$ \\
\hline $\begin{array}{c}\text { Awareness } \\
\text { (action strategies) }\end{array}$ & $\begin{array}{l}\text { Awareness of } \\
\text { action strategies } \\
\quad \text { (labels) }\end{array}$ & $\begin{array}{l}\text { Awareness of how to reduce } \\
\text { negative impacts from seafood } \\
\text { consumption is positively } \\
\text { correlated with SPES }\end{array}$ & [45] & $\begin{array}{l}\text { Recognition and stated } \\
\text { understanding of } \\
\text { eco-labels for seafood }\end{array}$ \\
\hline $\begin{array}{l}\text { Subjective } \\
\text { knowledge }\end{array}$ & $\begin{array}{c}\text { Subjective } \\
\text { knowledge } \\
\text { (subj. knowledge) }\end{array}$ & $\begin{array}{l}\text { Consumers' perceived } \\
\text { knowledge level is positively } \\
\text { correlated with SPES }\end{array}$ & {$[23,28]$} & $\begin{array}{l}\text { Consumer perceived } \\
\text { knowledge level }\end{array}$ \\
\hline Self-identification & $\begin{array}{l}\text { Pro-environmental } \\
\text { identity (identity) }\end{array}$ & $\begin{array}{l}\text { Consumers' identification as } \\
\text { environmentally conscious is } \\
\text { positively correlated } \\
\text { with SPES }\end{array}$ & {$[28,46]$} & $\begin{array}{l}\text { Perception of being an } \\
\text { environmentally-conscious } \\
\text { person and membership in } \\
\text { an environmental NGO }\end{array}$ \\
\hline $\begin{array}{l}\text { Personal } \\
\text { responsibility }\end{array}$ & $\begin{array}{l}\text { Sense of } \\
\text { responsibility } \\
\text { (responsibility) }\end{array}$ & $\begin{array}{l}\text { Consumers' sense of personal } \\
\text { responsibility positively } \\
\text { correlates with SPES }\end{array}$ & [37] & $\begin{array}{l}\text { Think that consumers } \\
\text { should have a major } \\
\text { responsibility for } \\
\text { sustainable production } \\
\text { of seafood }\end{array}$ \\
\hline $\begin{array}{l}\text { Environmental } \\
\text { concern }\end{array}$ & $\begin{array}{l}\text { Worry for negative } \\
\text { environmental } \\
\text { impacts (concern) }\end{array}$ & $\begin{array}{l}\text { Concern for environmental } \\
\text { impacts linked to seafood } \\
\text { production is positively } \\
\text { correlated with SPES }\end{array}$ & {$[29,30]$} & $\begin{array}{l}\text { Concern for } \\
\text { environmental impacts } \\
\text { from seafood production }\end{array}$ \\
\hline $\begin{array}{c}\text { Perceived } \\
\text { consumer } \\
\text { effectiveness (PCE) }\end{array}$ & $\begin{array}{c}\text { Perceived } \\
\text { consumer } \\
\text { effectiveness }(P C E)\end{array}$ & $\begin{array}{l}\text { The extent to which the } \\
\text { individual thinks he/she can } \\
\text { make a difference by buying } \\
\text { eco-labeled alternatives is } \\
\text { positively correlated } \\
\text { with SPES }\end{array}$ & {$[23,33]$} & $\begin{array}{l}\text { Beliefs that purchasing } \\
\text { eco-labeled seafood can } \\
\text { contribute to better } \\
\text { production practices }\end{array}$ \\
\hline- & Gender & $\begin{array}{l}\text { Women more likely to conduct } \\
\text { SPES than men }\end{array}$ & [37] & Gender \\
\hline- & Education & $\begin{array}{l}\text { Consumers with higher } \\
\text { education are more likely to } \\
\text { conduct SPES than those with } \\
\text { lower education }\end{array}$ & [37] & Level of education \\
\hline
\end{tabular}

\subsection{Data Collection}

Data were collected through a consumer questionnaire distributed in shopping malls in the Stockholm region (reachable by the public transport system) in October-December 2013. The locations were chosen to include a broad socio-economic segment of the population, and surveying was conducted between $10.00 \mathrm{a} . \mathrm{m}$. and $7.00 \mathrm{p} . \mathrm{m}$. on weekdays and weekends. The sampling strategy was to randomly approach respondents and ask if they were willing to participate in a research study on seafood consumption. The survey was self-administered by the respondents (questionnaire filled in individually at the time of surveying), and in total, 406 out of 500 distributed surveys were completed. The non-probability sampling strategy together with the method used to distribute surveys does not guarantee a statistically-representative sample of the Swedish population as a whole. Moreover, there is a risk that people interested in the topic of seafood consumption and eco-labeling participated to a higher extent than others. However, the demographic characteristics of the sample $(n=406)$ presented in Table 2 shows that a broad segment of the population was represented. There was a slight bias towards younger age segments (aged 18-54 years), women and people with children 
in the household. Respondents with a university degree were also overrepresented in the sample. The majority $(83 \%)$ was living in large urban areas ( $>250,000$ inhabitants) in Sweden, presumably in or around Stockholm.

Table 2. Demographic characteristics of the respondents participating in the study $(n=406)$.

\begin{tabular}{|c|c|c|c|c|c|c|c|}
\hline & & $\begin{array}{c}\text { This } \\
\text { Study (\%) }\end{array}$ & $\begin{array}{l}\text { Sweden * } \\
(2013)(\%)\end{array}$ & & & $\begin{array}{c}\text { This } \\
\text { Study }(\%)\end{array}$ & $\begin{array}{l}\text { Sweden * } \\
(2013)(\%)\end{array}$ \\
\hline \multirow{9}{*}{ Age } & $18-24$ & 11.8 & 9.6 & \multirow{2}{*}{ Education } & Lower education & 30.0 & 63.8 \\
\hline & $25-34$ & 24.1 & 16.4 & & University & 70.0 & 34.4 \\
\hline & $35-44$ & 20.7 & 16.7 & & & & \\
\hline & \multirow{2}{*}{$45-54$} & \multirow{2}{*}{15.0} & \multirow{2}{*}{17.1} & \multirow{2}{*}{$\begin{array}{l}\text { Member } \\
\text { in E-NGO }\end{array}$} & Yes & 18.2 & NA \\
\hline & & & & & No & 81.8 & NA \\
\hline & $55-64$ & 13.3 & 15.3 & & & & \\
\hline & \multirow{2}{*}{$65-74$} & \multirow{2}{*}{11.8} & \multirow{2}{*}{14.0} & \multirow{2}{*}{$\begin{array}{l}\text { Children in } \\
\text { household }\end{array}$} & Yes & 36.2 & 29.1 \\
\hline & & & & & No & 63.8 & 70.9 \\
\hline & $>75$ & 3.2 & 10.9 & & & & \\
\hline \multirow{2}{*}{ Gender } & $\mathrm{M}$ & 45.1 & 50.0 & & & & \\
\hline & $\mathrm{F}$ & 54.9 & 50.0 & & & & \\
\hline
\end{tabular}

\subsection{Operationalizing Explanatory Variables}

The survey instrument and information on how the questions were coded for the statistical analysis are presented in Appendix A and in Table A1. Shorter versions of the variables included in the statistical analysis are henceforth presented italicized in parenthesis (see also Table 1, Column 2). The purchasing behavior was captured by asking to what extent respondents buy eco-labeled seafood when available (five-point Likert scale). The objective environmental knowledge (obj. knowledge) related to fisheries and aquaculture was assessed through eight questions, half of them focusing on aquaculture and half on capture fisheries. Three potential answers were provided for each question, of which one was correct. Even though multiple-choice questions imply an inherent risk of participants obtaining the correct answer by speculating or by exclusion of unlikely answers, we argue that by including two false answers and only one correct, this risk can be considered small. A 'don't know' alternative was not included, since the objective was to force respondents to choose based on their current knowledge (see also, e.g., [48]). The final measure used in the analysis was the total number of correct answers (0-8). Awareness of action strategies (labels) was assessed by presenting eco-labels and asking respondents to state whether they recognized the logos or not and if they were aware of the meaning of the scheme (yes/no). The included schemes were selected to represent the Swedish market: Marine Stewardship Council (MSC), Aquaculture Stewardship Council (ASC), Fish for Life (Findus, industry led scheme) and KRAV (Swedish organic certification scheme). A fake eco-label (EcoFish) was also included in order to investigate the extent to which people tended to falsely state that they recognize a label.

For the remainder of questions, a five-point Likert scale was used to capture the extent of agreement/disagreement or perception. The perceived consumer effectiveness (PCE) was assessed by asking to what extent the respondents believed that they as individuals contribute to more sustainable production methods by purchasing eco-labeled seafood. To investigate consumers' subjective knowledge (subj. knowledge), we asked how the respondents perceive their knowledge level pertaining to seafood production. Concern (concern) was investigated by asking to what extent the respondents feel worried about negative environmental impacts from fisheries and aquaculture. Pro-environmental identity (identity) was measured through two separate questions, the first aiming 
to capture the self-perceived environmental consciousness and the second stated membership in an environmental organization ('yes' or 'no'). In order to assess the level of responsibility for seafood sustainability that respondents perceived should be attributed to different actors, the participants were asked to grade the level of responsibility for a number of societal groups and institutions. The measure for the variable responsibility (responsibility) was the extent respondents perceived that consumers' should be responsible for an environmentally-sustainable production of seafood. While it has been suggested that multi-item scales are preferred before single-item measures in survey instruments [49], single-item measures have also been demonstrated to accurately capture a certain factors [50], e.g., PCE [51]. The application of primarily single-item constructs in this study enabled us to assess a large range of factors using a survey instrument with a reasonable length.

Respondents' primary sources of information were investigated by asking where they learn about environmental impacts from capture fisheries/aquaculture. A number of key sources (retailers, authorities, environmental organizations, producers/fishermen, media and friends/colleagues) were listed for the respondents to rate. Additionally, information on seafood consumption level, as well as demographic variables (e.g., age, gender and education) was collected.

\subsection{Statistical Analysis}

General linear modeling and multi-model inference (MMI), an information theoretic approach [52,53], were used to examine the contribution of selected factors to stated purchasing behavior of eco-labeled seafood among consumers in the Stockholm region. MMI provides a set of potential models that all predict the dependent variable to a certain degree while also uncovering the relative importance of the explanatory variables included. A key benefit with this approach is that goodness of fit is rewarded, while inclusion of a high number of independent variables is penalized. Furthermore, MMI provides a more transparent selection of possible models than conventional multiple regression analysis, which traditionally only reports on the one most significant model [54].

Given the semi-explorative characteristics of this work, we included all nine of the explanatory variables outlined in the framework. Prior to conducting the multiple linear regression and MMI, multicollinearity between variables was tested for by investigating variance inflation factors (VIF $<2$ ) and the appropriateness of the full model containing all variables assessed by plotting residuals with fitted values and with a normal Q-Q plot. The strength of evidence for each model generated is indicated by Akaike's information criterion (AIC) and AICc, the latter measure including penalization for a higher number of model parameters. We use AICc in our interpretation because our sample $(n=371)$ to variable $(K=9)$ ratio is close to $40(371 / 9=41.2)$ (see [54] for more details). Models were compared by using $\triangle \mathrm{AICc}$ values, evidence ratios and Akaike weights $(\mathrm{w})$, where $\triangle \mathrm{AICC}=\mathrm{AICi}$ (the AIC for model i) - 'min AIC' (the AIC value for the best model). A model with a $\triangle \mathrm{AICC}>2$ can be considered comparatively poor at explaining the dependent variable (corresponds with an evidence ratio of 2.7; Burnham et al., 2011); thus, we only present models with $\Delta \mathrm{AICC}<2$ in detail in the Results section. $\triangle$ AIC can be translated to evidence ratios, which indicate the relative likelihood of model i versus model $\mathrm{j}$ [52]. Akaike weights (wi) indicate the likelihood that a particular model is the top one for the sampling situation considered. A higher weight indicates a better fit. In combination, these three measures assist in the interpretation of the relative importance of each model. MMI analysis was done using the dredge function in the R MuMin package (R Development Core Team 2011).

\section{Results}

The first three parts of the Results Sections 3.1-3.3 provide descriptive statistics of the stated purchasing of eco-labeled seafood, respondents subjective and objective knowledge along with PCE, self-identification and level of concern. Except for 'source of environmental information' $(n=396)$, 406 respondents were represented in the descriptive statistics. In Section 3.4, the results from the statistical analysis (MMI) are presented $(n=371)$. The smaller sample size is due to several 'don't know' responses in the large sample $(n=406)$, not possible to include in the statistical analysis. 


\subsection{Respondents and Seafood Purchasing}

The majority of the respondents purchased seafood in grocery stores at least once per week $(41 \%)$ or per month $(49 \%)$. A minority (16\%) stated that they always buy eco-labeled seafood when available, whereas $68 \%$ reported to sometimes purchase eco-labeled seafood (3-4 on a five-point scale). The average rate (1-5) of stated purchasing of eco-labeled seafood was $3.43( \pm 1.00)(\mathrm{SD})$.

\subsection{Objective and Subjective Knowledge}

Most participants (78\%) perceived themselves to have a low or moderate level of knowledge (1-3 on a five-point scale) pertaining to production of seafood (average $2.5 \pm 1.23$ ). The objective knowledge question with the highest rate of correct answers related to northern prawns, followed by a question about farming of tropical shrimp (Table 3). None of the eight questions had a correct response rate above $74 \%$, indicating a fairly low level of factual knowledge related to seafood production.

Table 3. Survey questions aiming to capture respondents' objective knowledge pertaining to seafood production. $n=406$.

\begin{tabular}{|c|c|c|c|c|}
\hline & Question & Correct Answer & Reference & $\begin{array}{c}\text { Correct Answers (\%) } \\
n=406\end{array}$ \\
\hline 1. & Salmon is most often farmed in & Net pens in the ocean & [55] & 59.9 \\
\hline 2. & $\begin{array}{l}\text { Mussel farming can have a positive } \\
\text { impact on the environment since they }\end{array}$ & $\begin{array}{l}\text { Absorb nutrients } \\
\text { in the water }\end{array}$ & [56] & 61.1 \\
\hline 3. & $\begin{array}{l}\text { Farming of tropical shrimp has been } \\
\text { criticized for }\end{array}$ & $\begin{array}{l}\text { Mangrove deforestation } \\
\text { to build dams }\end{array}$ & [57] & 65.3 \\
\hline 4. & $\begin{array}{l}\text { Pangasius, striped catfish, sold in } \\
\text { Sweden most often comes from }\end{array}$ & Vietnam & [58] & 52.0 \\
\hline 5. & $\begin{array}{l}\text { The national food agency recommends } \\
\text { limited consumption of Baltic herring } \\
\text { because of high levels of }\end{array}$ & Dioxin & [59] & 64.5 \\
\hline 6. & $\begin{array}{l}\text { Which of the following species are 'ok } \\
\text { to eat' in terms of environmental } \\
\text { sustainability, according to the fish } \\
\text { guide from World Wildlife Fund (WWF) } \\
\text { Sweden (2012) }\end{array}$ & Lobster (cages) & {$[60]$} & 52.5 \\
\hline 7. & $\begin{array}{l}\text { Northern prawns are fished mainly } \\
\text { through the use of }\end{array}$ & Trawls & [61] & 73.2 \\
\hline 8. & $\begin{array}{l}\text { Wild caught fish sold in Sweden is often } \\
\text { labeled "FAO 27". What does "FAO 27" } \\
\text { stand for? }\end{array}$ & $\begin{array}{l}\text { Caught in the } \\
\text { Northeast Atlantic }\end{array}$ & [62] & 61.6 \\
\hline
\end{tabular}

The level of recognition and perceived understanding of labels was for the majority of eco-labels low to moderate (Table 4). The one exception was the Swedish KRAV label, which $94 \%$ of the respondents recognized. The most common eco-label for seafood on the Swedish market at the time of writing was the MSC label, solely recognized by $44 \%$ of the respondents and understood by $13 \%$. Interestingly, $17 \%$ (more than one out of six) of the respondents stated that they recognized the fake label, implying that the actual level of recognition and understanding of the labels might be lower than as indicated by the results.

The main source of information (4-5 on a five-point scale) was media $(55 \%)$, followed by environmental NGOs (40\%) and friends/colleagues (36\%). The information sources least accessed were retailers $(7 \%)$ and fishermen/farmers $(10 \%)$. 
Table 4. Consumers' recognition of eco-labels for seafood available on the Swedish market. $n=406$. KRAV, Swedish organic scheme; MSC, Marine Stewardship Council; ASC, Aquaculture Stewardship Council.

\begin{tabular}{cccc}
\hline & Recognize (\%) & Recognize and Know Meaning (\%) & Total Recognition (\%) \\
\hline KRAV & 39.7 & 54.7 & 94.3 \\
MSC & 31.3 & 12.8 & 44.1 \\
Fish for Life & 19.5 & 4.7 & 24.1 \\
ASC & 18.7 & 4.4 & 23.2 \\
EcoFish (fake label) & 14.3 & 2.7 & 17.0 \\
\hline
\end{tabular}

\subsection{Environmental Concern and Pro-Environmental Self-Identification}

More than half of the respondents $(57 \%)$ stated that they feel worried about negative environmental impacts related to seafood production (4-5 on a five-point scale), and $44 \%$ perceived themselves to be environmentally conscious ( $4-5$ on a five-point scale). The majority ( $63 \%)$ stated a high level (4- 5 on a five-point scale) of PCE. Authorities (through provision of information), the government and seafood companies were identified to have the highest responsibility for sustainable seafood production, whereas consumers were stated as having the least responsibility (only $23 \%$ of the respondents rated the consumer responsibility as very high, i.e., five on a five-point scale).

\subsection{Statistical Results}

A total of 371 surveys were completed with respect to all nine variables included in the full model. Prior to conducting the multiple linear regression and MMI, multicollinearity between variables was tested for $(\mathrm{VIF}<2)$. The full model containing all nine independent variables explained $25.4 \%$ of the variation in stated purchasing behavior of eco-certified seafood (adjusted $R^{2}$ ). Multi-model inference yielded 512 candidate models. A total of eleven models exhibited $\triangle \mathrm{AICc}<2$ and accounted for $43 \%$ of the total AIC weights (Table 5). The best model contained the variables labels, concern, identity, PCE, obj. knowledge and responsibility and had an AIC weight of $6 \%$. Models including one of the factors labels or concern accounted for $100 \%$ of the cumulative weight of all of the 512 possible models, indicating a substantial importance of these two variables. Identity and PCE (accounting for $91 \%$ and $78 \%$ of cumulative weight, respectively) were also included in the majority of the high weight models and can thus also be considered relevant (Figure C1, Appendix C).

Table 5. The best models generated by multi-model inference $(\mathrm{MMI})(\triangle \mathrm{AIC}<2)$ and $\triangle \mathrm{AICc}$ values, cumulative weights and evidence ratios for each model. Subjective knowledge was not included in any of the top models. $n=371$.

\begin{tabular}{|c|c|c|c|c|c|c|c|c|c|c|c|}
\hline & Labels & Concern & Identity & PCE & obj. know. & resp. & Gender & edu. & $\triangle \mathrm{AICc}$ & $\begin{array}{c}\text { Cum. } \\
\text { Weight }\end{array}$ & $\begin{array}{c}\text { Evidence } \\
\text { Ratio }\end{array}$ \\
\hline 1 & $x$ & $x$ & $x$ & $x$ & $x$ & $x$ & & & 0.00 & $6.1 \%$ & 1.00 \\
\hline 2 & $x$ & $x$ & $x$ & $x$ & $x$ & & & & 0.04 & $12.0 \%$ & 1.02 \\
\hline 3 & $x$ & $x$ & $x$ & $x$ & $x$ & $x$ & $x$ & & 0.29 & $17.3 \%$ & 1.15 \\
\hline 4 & $x$ & $x$ & $x$ & $x$ & $x$ & & $x$ & & 0.33 & $22.4 \%$ & 1.18 \\
\hline 5 & $x$ & $x$ & $x$ & $x$ & & & & & 0.77 & $26.5 \%$ & 1.47 \\
\hline 6 & $x$ & $x$ & $x$ & $x$ & & $x$ & & & 1.01 & $30.2 \%$ & 1.65 \\
\hline 7 & $x$ & $x$ & $x$ & $x$ & $x$ & & & $x$ & 1.56 & $33.0 \%$ & 2.18 \\
\hline 8 & $x$ & $x$ & $x$ & $x$ & & & $x$ & & 1.66 & $35.6 \%$ & 2.29 \\
\hline 9 & $x$ & $x$ & $x$ & $x$ & $x$ & $x$ & & $x$ & 1.74 & $38.2 \%$ & 2.38 \\
\hline 10 & $x$ & $x$ & $x$ & $x$ & $x$ & & $x$ & $x$ & 1.86 & $40.6 \%$ & 2.54 \\
\hline 11 & $x$ & $x$ & $x$ & $x$ & & $x$ & $x$ & & 1.92 & $42.9 \%$ & 2.61 \\
\hline
\end{tabular}

The evidence ratio for a particular model demonstrates the strength of evidence compared with the best model. The results from this study showed that the evidence for Model 1 is 2.6-times stronger than for Model 11 (Table 5). To illustrate the interpretation procedure, we removed the top three most 
important variables (labels, concern and identity) from the best model. The evidence ratios of the new models increased by a factor between six and 27,116, indicating the relative importance of each of the explanatory factors removed (Table 6). Another interpretation exercise was to include only the top two variables (concern and labels) in a model. This gave a $\triangle \mathrm{AICc}$ of 11.6, corresponding to an evidence ratio of 329, implying that the model is 329-times less likely than the best model. When identity was added to this model (containing concern and labels), the evidence ratio increased to six (Table 6), substantially improving the model fit and providing substantial support for the conclusion that labels, concern and identity were the three most important variables in explaining stated purchasing behavior of eco-labeled seafood among consumers in Stockholm.

Table 6. The best model generated by MMI $(\triangle \mathrm{AICC}=0)$ with modifications (variables removed), and the two models solely including the top three variables (concern, labels and identity).

\begin{tabular}{cccccc}
\hline Model & Rank & Df & AAICc & Weight & Evidence Ratio \\
\hline Best model (labels + concern + identity + PCE + & 1 & 8 & 0.0 & $6.1 \%$ & 1.0 \\
obj. know. + resp.) & 132 & 7 & 17.2 & $0.0 \%$ & 5454.9 \\
Best model minus concern & 154 & 7 & 20.4 & $0.0 \%$ & $27,115.7$ \\
Best model minus labels & 30 & 7 & 3.7 & $0.9 \%$ & 6.4 \\
Best model minus identity & 117 & 4 & 11.6 & $0.0 \%$ & 328.6 \\
Model only including concern + labels & 33 & 5 & 3.8 & $0.9 \%$ & 6.3 \\
\hline Model only including concern + labels + identity & & & & \\
\hline
\end{tabular}

We further multiplied the standardized $\beta$-coefficients for the variables included with the weight of each individual model to get model averaging. This measure provided information on the predictive power of each explanatory variable included in the original model. The result (including shrinkage) is presented in Figure 2. For more information on the multimodel averaging step and shrinkage, see Appendix B. Concern and labels were the two variables with highest explanatory power $(\beta=0.24$ and 0.23 , respectively), followed by identity and $P C E$ ( $\beta=0.12$ and 0.08 , respectively).

A linear multiple regression analysis including the variables in the best model (labels + concern + identity $+P C E+o b j$. know. + responsibility) was conducted as part of the MMI step in order to obtain information on which variables are statistically significant. Labels and concern $(p<0.01)$, as well as identity and PCE $(p<0.05)$ were the statistically-significant variables in the model (and also the variables with the highest model averaged effect sizes; Figure 2). The adjusted $R^{2}$ value for the full model was 0.26 .

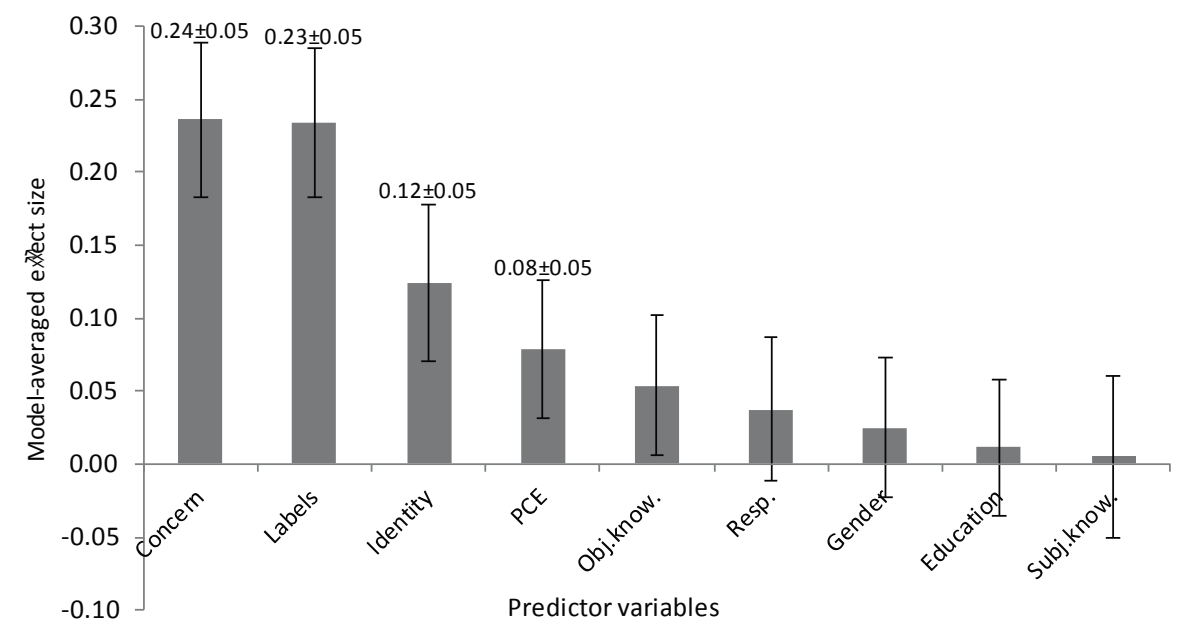

Figure 2. Model averaged effect sizes with shrinkage for the independent variables included in the global model. Estimated coefficients with shrinkage and model averaged adjusted standard errors for the top most important variables. $n=371$. 


\section{Discussion}

The first aim of this study was to assess the level of consumer environmental knowledge pertaining to aquatic food production systems and to investigate which sources of information that are most frequently used. The limited level of knowledge about seafood production systems and environmental impacts from capture fisheries and aquaculture found in this study agrees with results from earlier work, e.g., $[12,63,64]$. The extent of label recognition differed substantially between logos presented, ranging from $95 \%$ for the organic label KRAV to only $23 \%$ for ASC. Noteworthy is the rather low level of recognition of the MSC label (43\%), the largest seafood eco-label in Sweden. However, the results are consistent with earlier investigations of familiarity with the MSC label in Sweden (45\%) [65] and higher than the average of consumers from 15 countries (33\%) [66]. Since label recognition was one of the most important variables in predicting stated purchasing of eco-labeled seafood, we suggest that efforts need to be directed towards increasing consumers' familiarity and understanding of seafood eco-labels. Retailers could potentially play a key role when it comes to the provision of information for two reasons: first, because they offer an arena where consumers are likely to be susceptible to information while making purchasing decisions [67]; and second, retailers were, together with seafood producers, stated as the least important provider of environmental information pertaining to seafood production (average $1.9 \pm 1.0$ on a five-point scale), indicating room for improvement. However, it should be noted that the reason for the low use of retailers as a source of information is unknown and that lack of trust for commercial actors might be a barrier for consumer awareness making. Media and environmental NGOs (stated to be the most frequently-used sources of information, also supported by [68]) are other potentially important actors in increasing consumers' familiarity with seafood eco-labels.

The second objective of this study was to investigate the relative importance of internal factors (i.e., consumer characteristics) predicted to affect purchasing of eco-labeled seafood. The findings support the hypothesis that cognitive (labels), as well as emotional (concern) elements predict consumers' stated purchasing behavior of eco-labeled seafood products. While the negative framing of the question on the degree of consumer concern may lead to a slight bias towards an expressed worry among respondents, a certain framing is inevitable and is not judged to have any substantial impact on the results. Awareness of action strategies has been highlighted in the literature as an important cognitive predictor for pro-environmental behavior [37,45]. We argue that for most consumers, choosing eco-labeled alternatives is the most feasible action strategy, although other approaches, such as seafood recommendation lists, are also viable alternatives [69]. Our results show that recognition of eco-labels for seafood (together with concern for negative environmental impacts) constitutes the variable that most strongly influences respondents' stated purchasing of eco-labeled seafood. This result supports recent findings where recognition and understanding of eco-labels for food products was positively correlated with label use [70]. Our results also corroborate findings from earlier work stressing that concern for environmental impacts from seafood production is positively correlated with stated purchasing of eco-labeled seafood $[6,10,12]$. Level of concern was weakly, yet significantly, positively correlated with recognition of seafood eco-labels (linear regression, $R^{2}=0.06, p<0.01$ ). Grunert et al. [70] similarly found a weak positive correlation between concern about sustainability issues (environmental and social) related to food production and use of information provided by sustainability labels.

Though concern and awareness of eco-labels were the two most important variables predicting stated purchasing of eco-labeled seafood, two other internal factors were also highly relevant. Identity and PCE both predicted significant effects on stated purchasing of eco-labeled seafood in the best model. The importance of the predictors self-identification and membership in an environmental organization (here, captured by identity) has been identified in previous work [8,28]. Perceived consumer effectiveness $(P C E)$ was the fourth most important variable in predicting stated purchasing behavior and is likely an important component of the decision making process, since it implies a perception that the individual's actions are of significance. There was little evidence in our findings that demographic variables had an effect on stated purchasing of eco-labeled seafood. The lack of 
relationship between gender or level of education and pro-environmental behavior is in line with earlier research showing limited effects of demographic factors [71]. However, it contrasts with work showing that female and well-educated consumers are more prone to buy eco-labeled seafood alternatives than are other people [12,13,72].

Limited knowledge on how food is produced and the environmental implications of production has been conceptualized as food illiteracy [73] and could constitute a barrier for sustainable food consumption. Though the results from this study showed that objective environmental knowledge is a comparatively weak predictor of stated purchasing of eco-labeled seafood, there appears to be an association between the cognitive and emotional components of consumer decision making [74]. Provision of environmental knowledge may induce an emotional response stimulating pro-environmental behavior [75], and the other way around, an individual who is emotionally engaged might be more prone to search for knowledge in order to learn more about how food is produced and the environmental effects of production practices (both positive and negative) [76]. The link between subjective knowledge pertaining to marine environmental impacts and level of concern has been highlighted in recent research [68], supporting the association between self-identification and emotional engagement. The level of subjective knowledge in this study is consistent with earlier work dealing with seafood consumers' self-stated level of knowledge (e.g., [14]). However, in contrast to work by $[23,25]$, the results from multi-model averaging indicate that objective knowledge is a better predictor of eco-labeled seafood purchasing than subjective knowledge. Worth noting, however, is that both variables (obj. knowledge and subj. knowledge) were weak predictors of eco-labeled seafood purchase compared with other variables.

The average frequency of stated purchasing eco-labeled seafood in this study was $3.43 \pm 1.00$ (mean $\pm \mathrm{SD}$ ) on a five-point scale, indicating that the majority of respondents state that they sometimes choose an eco-labeled seafood alternative when available. Important to note here is that $39 \%$ of the yearly sales value (2013/2014) of frozen seafood in Sweden currently is eco-labeled by the MSC, and $2 \%$ is labeled as organic [77]. Some of the respondents participating in this study might thus choose eco-labeled seafood unintentionally, but state otherwise in the questionnaire. It is, however, worth considering that a relatively small proportion of farmed and fresh seafood (both farmed and wild-caught) is eco-labeled in Sweden. This should be viewed in the context of two clear trends in Swedish seafood retailing: (a) that the demand for salmon (by the time of writing, the most popular seafood), of which the great majority is farmed, has increased substantially in the last few years (34\% increase in the volume sold between 2010 and 2012); and (b) that the demand for fresh seafood has increased at the expense of frozen, conserved and canned seafood [78]. The results of this work could therefore be of interest for actors aiming to shift farmed and fresh seafood consumption (as well as non-labeled wild-caught frozen seafood) towards improved sustainability.

The relatively low explanatory power of the best linear regression model generated by MMI (adjusted $R^{2}$ 0.26) indicates that additional factors, most likely external, e.g., price and availability, influence whether consumers choose to buy eco-labeled seafood alternatives. Internal factors not specifically measured in this study, e.g., positive feelings of purchasing labeled alternatives, could also affect the demand for eco-labeled seafood. Given the potential existence of an intention-behavior gap [39], a possible weakness of this study is that the measure for sustainable seafood consumption was restricted to individuals' stated behavior and not complemented by figures on revealed preferences, e.g., market observations or experimental data. Moreover, we acknowledge that using Stockholm and Sweden as a case may limit the applicability of results to regions where the interest for ethical consumption is relatively high. However, on the other hand, results from this study pointing towards a low level of awareness of negative environmental impacts and seafood eco-labels among consumers in presumably one of the most pro-environmental consumption-oriented markets in the world are likely of relevance for the sustainable seafood movement as a whole. While this study investigated factors influencing stated purchasing of eco-labeled seafood, we recognize that consumer demand is only one out of many potential drivers towards increasing the share of eco-certified seafood on global 
markets and enhancing the environmental sustainability of the seafood sector. Other mechanisms (e.g., consumer choice editing by retailers and wholesalers, implementation of legislation and code of conducts for production) are also highly relevant, particularly in emerging economies where pro-environmental consumption is a relatively recent and immature phenomenon.

\section{Conclusions}

If eco-certification directed towards consumers is to be an effective tool for reducing negative environmental impacts from aquaculture and fisheries, consumer (and/or retailer) demand for eco-labeled seafood products needs to increase. Our empirical analysis in the Stockholm area, Sweden, revealed some of the key internal factors that appear important for predicting pro-environmental seafood consumption behavior. Early models of pro-environmental behavior stressed the significance of the provision of information and knowledge creation in the process of altering human behavior. Though these rather simplistic models were rejected decades ago by the large majority of scholars [37], a primary focus of UN organs and NGO-led campaigns aiming to promote pro-environmental consumption has still been on increasing the level of environmental knowledge in order to alter consumer behavior. This study confirms results from earlier work demonstrating the limitations of focusing solely on the provision of information in shifting consumer behavior towards more environmentally sustainable practices. Findings show that awareness of action strategies, in our case recognition and stated understanding of eco-labels, can be a more important predictor of stated eco-labeled seafood purchasing and, thus, that consumers' familiarity with labels needs to increase. While an increased level of objective knowledge most likely influences the level of concern for negative environmental impacts, we argue that consumer-oriented campaigns should increasingly take emotive aspects into consideration, e.g., by providing emotionally engaging narratives, and thereby create long-lasting pro-environmental attitudes towards eco-labeled seafood.

Acknowledgments: This work was supported by Sida (the Swedish International Development Cooperation Agency), the Swedish Research Council VR (proj. No. SWE-2011-38) and the Erling-Persson Family Foundation through the 'Global Economic Dynamics and the Biosphere' program. The authors thank Johan Eklöf and Therese Lindahl for valuable comments on an earlier version of this manuscript.

Author Contributions: Malin Jonell, Beatrice Crona, Patrik Rönnbäck and Max Troell designed the survey and wrote the paper. Kelsey Brown and Malin Jonell conducted all of the data collection. Malin Jonell, Beatrice Crona and Kelsey Brown performed the statistical analysis. All authors read and approved the final manuscript and participated in joint discussions.

Conflicts of Interest: The authors declare no conflict of interest.

\section{Appendix A}

\section{Appendix A.1. Questionnaire}

I How often do you buy seafood in grocery stores?

- Once/a couple of times per week

- Once/a couple of times per month

- Once/a couple of times per year

$-\quad$ Never

II Do you buy eco-labeled seafood (e.g., KRAV, MSC) when available?

$$
\begin{array}{ll}
- & \text { No } \\
- & \text { Not very often } \\
- & \text { Sometimes, } \\
- & \text { Often, } \\
- & \text { Yes, always }
\end{array}
$$


III To what extent do you think you as a consumer contribute to more sustainable aquaculture and fisheries practices by purchasing eco-labeled seafood alternatives?

1 . Not at all $\rightarrow 5$. In a very high extent

Don't know

IV Do you recognize the following eco-labels for seafood?

Labels presented: MSC, ASC, Fish for Life EcoFish and KRAV

- Don't recognize

- Recognize

- $\quad$ Recognize and know the meaning of the scheme

$\mathrm{V}$ How do you perceive your knowledge level when it comes to how seafood is produced (aquaculture and capture fisheries)?

1. I perceive I have a relatively low level of knowledge $\rightarrow 5$. I feel relatively knowledgeable

VI Choose the alternative you believe is the correct one.

(1) Salmon is farmed in: (a) Ponds on land; (b) Net pens in the ocean; (c) Indoor ponds

(2) Mussel farming can have a positive impact on the environment since they: (a) Functions as spawning-grounds for cod; (b) Can decrease the amount of nutrients in the water; (c) Functions as nurseries for eels

(3) Farming of tropical prawns has been criticized for: (a) Logging of rainforest to build dams; (b) To cause acidification in tropical countries; (c) Mangrove deforestation to build dams

(4) Pangasius, Striped catfish, sold in Sweden most often comes from: (a) Vietnam; (b) Thailand; (c) Norway

(5) The national food agency recommends limited consumption of Baltic herring because of high levels of: (a) DDT; (b) Dioxin; (c) Antibiotics

(6) Which of the following species are 'ok to eat' in terms of environmental sustainability according to the fish guide from WWF Sweden (2012): (a) Swordfish; (b) Monkfish; (c) Lobster (cages)

(7) Northern prawns are fished mainly through the use of: (a) Drift nets; (b) Trawling; (c) Cages

(8) Wild caught fish sold in Sweden is often labeled "FAO 27". What does "FAO 27" stand for?, (a) Caught in the Northeast Atlantic; (b) caught in the Baltic Sea; (c) Caught in Kattegatt

I From where do you obtain information on environmental impacts from capture fisheries/aquaculture from?

Sources presented: Retailers/groceries, Authorities, Environmental NGOs, Producers/fishermen, Media, Friends/colleagues and Own alternative

1. Get no information from $\rightarrow 5$. Get a lot of information from

II Do you feel worried about negative environmental impacts from fisheries and aquaculture?

1 . No, not at all $\rightarrow 5$. Yes, very worried

Don't know

III Do you perceive yourself as an environmentally conscious person?

1. No, not at all $\rightarrow 5$. Yes, definitely 
IV To what extent should the following actors be responsible for an environmentally sustainable production of seafood?

Actors presented:

Consumers, Retailers/groceries, Authorities (through provision of information), The government (legislation), Environmental NGOs, Companies (importers/wholesale dealers), Media (newspapers/radio/TV) and Own alternative

1. Should not have any responsibility $\rightarrow 5$. Should have major responsibility

V Age

$<24 ; 25-34 ; 35-44 ; 45-54 ; 55-65 ; 65-74 ;>74$

VI Gender

- Male

- Female

- Other

VII Education

- $\quad$ Not finalized primary school

- Primary school

- High school/upper secondary school

- University

VIII Place of residence

- Stockholm, Gothenburg, Malmö ( $>250,000$ inhabitants)

- City (30,000-249,999 inhabitants)

- $\quad$ Smaller city (200-29,999 inhabitants)

- Countryside (<200 inhabitants)

IX Are there any children in the household?

- Yes

- No

$\mathrm{X}$ Are you member in any environmental organization?

$-\quad$ Yes

$-\quad$ No

Appendix A.2. Coding Questions from Questionnaire for Statistical Analysis

The questions aiming to capture factors of interest for the statistical analysis (MMI) were coded in order to translate qualitative variables to quantitative measures (Table A1). The dependent variable (stated purchasing of eco-labeled seafood, Question II) was coded according to the five-point Likert scale provided (1-5 points). 
Table A1. Coding of questions from the questionnaire in preparation for statistical analysis of which factors are correlated with purchasing of eco-labeled seafood.

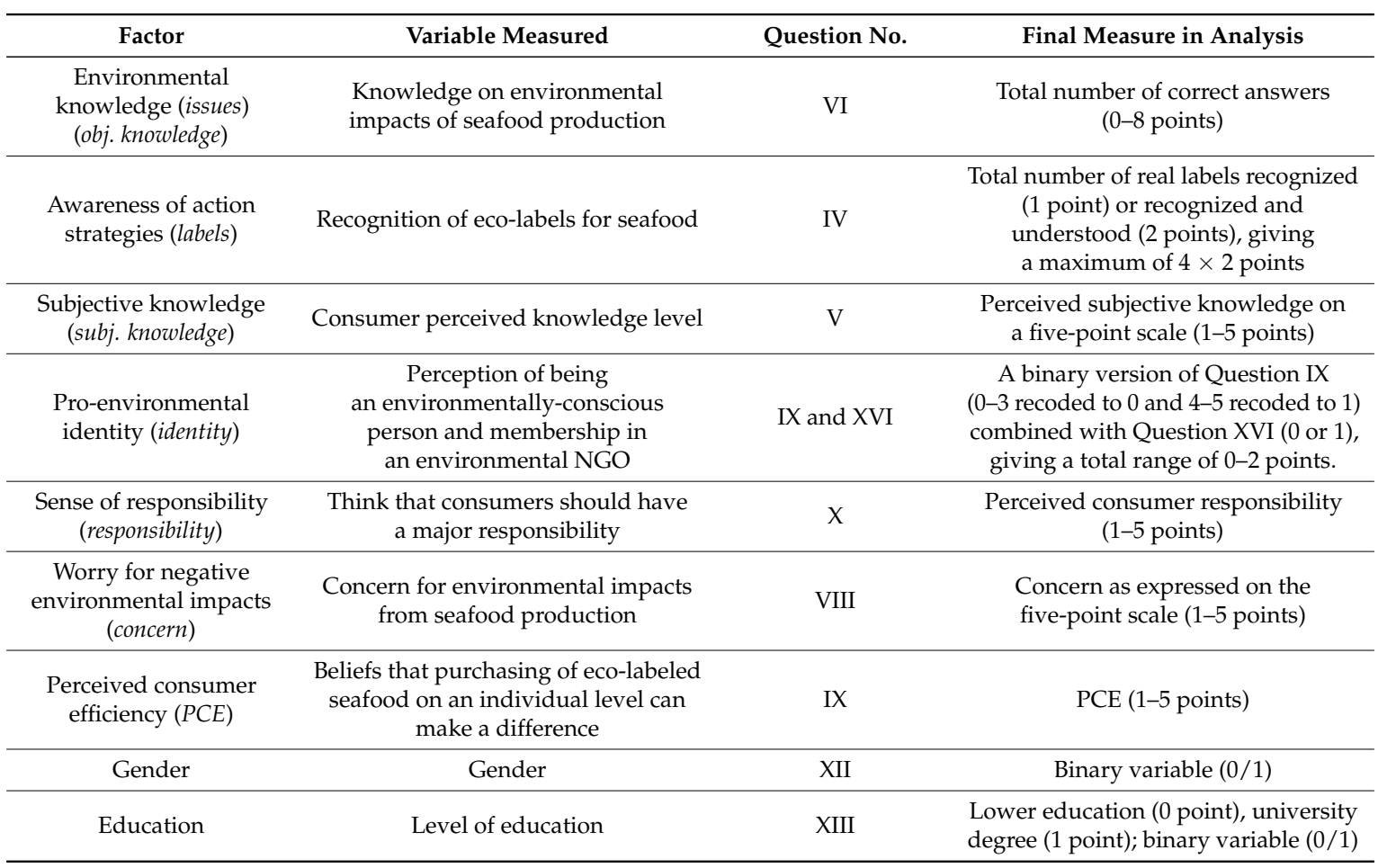

\section{Appendix B. Model Averaging}

Model averaging implies multiplying the standardized $\beta$-coefficients for each variable included in the full model with the model weight for each model in order to obtain a weighted estimate of the $\beta$-coefficient across all models. Since the support of the best models was moderate (the AIC weight of the best model was 0.06), we decided to conduct model averaging, including shrinkage, or full model averaging, thus include all of the models $(n=512)$ in the calculation [53]. For a model where the variable of interest is not included, the model weight is multiplied by zero. This implies that a variable included primarily in low weight models will be "punished" through a smaller model averaged $\beta$-coefficient than a variable included in high weight models.

\section{Appendix C}

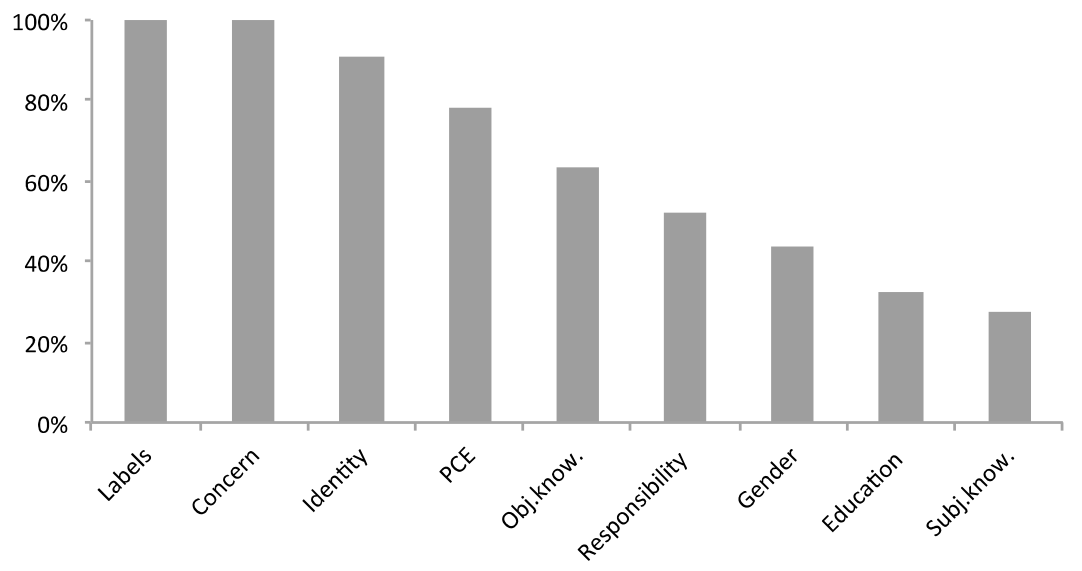

Figure C1. Importance of the explanatory variables expressed as the cumulative weights of models containing the variable. "Labels" and "concern" were included in all of the high weight models and therefore had a cumulative weight of $100 \%$. 


\section{References}

1. Pauly, D.; Christensen, V.; Guénette, S.; Pitcher, T.J.; Sumaila, U.R.; Walters, C.J.; Watson, R.; Zeller, D. Towards sustainability in world fisheries. Nature 2002, 418, 689-695. [CrossRef] [PubMed]

2. Troell, M.; Kautsky, N.; Beveridge, M.; Henriksson, P.; Primavera, J.; Rönnbäck, P.; Folke, C. Aquaculture. In Encyclopedia of Biodiversity, 2nd ed.; Levin, S.A., Ed.; Academic Press: Waltham, MA, USA, 2013; Volume 1, pp. 189-201.

3. Rist, L.; Felton, A.; Nyström, M.; Troell, M.; Sponseller, R.A.; Bengtsson, J.; Österblom, H.; Lindborg, R.; Tidåker, P.; Angeler, D.G.; et al. Applying resilience thinking to production ecosystems. Ecosphere 2014, 5, 1-11. [CrossRef]

4. $\quad$ MSC. MSC Global Impacts Report 2014; MSC: London, UK, 2014; p. 44.

5. Jonell, M.; Phillips, M.; Rönnbäck, P.; Troell, M. Eco-Certification of Farmed Seafood: Will It Make a Difference? Ambio 2013, 42, 659-674. [CrossRef] [PubMed]

6. Roheim, C.A.; Sudhakaran, P.O.; Durham, C.A. Certification of Shrimp and Salmon for Best Aquaculture Practices: Assessing Consumer Preferences in Rhode Island. Aquac. Econ. Manag. 2012, 16, 266-286. [CrossRef]

7. Johnston, R.J.; Roheim, C.A. A Battle of Taste and Environmental Convictions for Ecolabeled Seafood: A Contingent Ranking Experiment. J. Agric. Resour. Econ. 2006, 31, 283-300.

8. Johnston, R.J.; Wessells, C.R.; Donath, H.; Asche, F. Measuring Consumer Preferences for Ecolabeled Seafood: An International Comparison. J. Agric. Resour. Econ. 2001, 26, 20-39.

9. Uchida, H.; Roheim, C.A.; Wakamatsu, H.; Anderson, C.M. Do Japanese consumers care about sustainable fisheries? Evidence from an auction of ecolabelled seafood. Aust. J. Agric. Resour. Econ. 2013, 57, 1-18. [CrossRef]

10. Wessells, C.R.; Johnston, R.J.; Donath, H. Assessing consumer preferences for ecolabeled seafood: The influence of species, certifier, and household attributes. Am. J. Agric. Econ. 1999, 81, 1084-1089. [CrossRef]

11. Honkanen, P.; Young, J.A. What determines British consumers' motivation to buy sustainable seafood? Br. Food J. 2015, 117, 1289-1302. [CrossRef]

12. Brécard, D.; Hlaimi, B.; Lucas, S.; Perraudeau, Y.; Salladarré, F. Determinants of demand for green products: An application to eco-label demand for fish in Europe. Ecol. Econ. 2009, 69, 115-125. [CrossRef]

13. Salladarré, F.; Guillotreau, P.; Perraudeau, Y.; Monfort, M.-C. The Demand for Seafood Eco-Labels in France. J. Agric. Food Ind. Organ. 2010. [CrossRef]

14. Verbeke, W.; Vanhonacker, F.; Sioen, I.; van Camp, J.; de Henauw, S. Perceived importance of sustainability and ethics related to fish: A consumer behavior perspective. Ambio 2007, 36, 580-585. [CrossRef]

15. Whitmarsh, D.; Wattage, P. Public attitudes towards the environmental impact of salmon aquaculture in Scotland. Eur. Environ. 2006, 16, 108-121. [CrossRef]

16. Roheim, C.A.; Asche, F.; Santos, J.I. The Elusive Price Premium for Ecolabelled Products: Evidence from Seafood in the UK Market. J. Agric. Econ. 2011, 62, 655-668. [CrossRef]

17. Sogn-Grundvåg, G.; Larsen, T.A.; Young, J.A. The value of line-caught and other attributes: An exploration of price premiums for chilled fish in UK supermarkets. Mar. Policy 2012, 38, 41-44. [CrossRef]

18. Boström, M.; Klintman, M. Eco-Standards, Product Labelling and Green Consumerism; Palgrave MacMillan: Houndmills, UK, 2008.

19. Röös, E.; Tjärnemo, H. Challenges of carbon labelling of food products: A consumer research perspective. Br. Food J. 2011, 113, 982-996. [CrossRef]

20. Ekoweb. Ekologisk Livsmedelsmarknad. 2016. Available online: http://www.e-pages.dk/maskinbladet/ 1180/html5/ (accessed on 8 June 2016). (In Swedish)

21. Magnusson, M.K.; Arvola, A.; Hursti, U.-K.K.; Åberg, L.; Sjödén, P.-O. Attitudes towards organic foods among Swedish consumers. Br. Food J. 2001, 103, 209-226. [CrossRef]

22. Seyfang, G. Shopping for Sustainability: Can Sustainable Consumption Promote Ecological Citizenship? Env. Politics 2005, 14, 290-306. [CrossRef]

23. Ellen, P.S. Do We Know What We Need to Know? Objective and Subjective Knowledge Effects on Pro-Ecological Behaviors. J. Bus. Res. 1994, 30, 43-52. [CrossRef]

24. Grunert, K.G.; Wills, J.M. A review of European research on consumer response to nutrition information on food labels. J. Public Health (Bangkok) 2007, 15, 385-399. [CrossRef] 
25. Pieniak, Z.; Aertsens, J.; Verbeke, W. Subjective and objective knowledge as determinants of organic vegetables consumption. Food Qual. Preference 2010, 21, 581-588. [CrossRef]

26. Rousseau, S.; Vranken, L. Green market expansion by reducing information asymmetries: Evidence for labeled organic food products. Food Policy 2013, 40, 31-43. [CrossRef]

27. Pieniak, Z.; Verbeke, W.; Scholderer, J.; Brunso, K.; Olsen, S.-O. European consumers' use of and trust in information sources about fish. Food Qual. Preference 2007, 18, 1050-1063. [CrossRef]

28. Sparks, P.; Shepherd, R. Self-Identity and the Theory of Planned Behavior: Assesing the Role of Identification with “Green Consumerism". Soc. Psychol. Q. 1992, 55, 388-399. [CrossRef]

29. Grob, A. A structural model of environmental attitudes and behaviour. J. Environ. Psychol. 1995, 15, $209-220$. [CrossRef]

30. Roberts, J.A.; Bacon, D.R. Exploring the Subtle Relationships between Environmental Concern and Ecologically Conscious Consumer Behavior. J. Bus. Res. 1997, 40, 79-89. [CrossRef]

31. Peattie, K. Green Consumption: Behavior and Norms. Annu. Rev. Environ. Resour. 2010, 35, $195-228$. [CrossRef]

32. Straughan, R.D.; Roberts, J.A. Environmental segmentation alternatives: A look at green consumer behavior in the new millennium. J. Consum. Mark. 1999, 16, 558-575. [CrossRef]

33. Vermeir, I.; Verbeke, W. Sustainable Food Consumption: Exploring the Consumer "Attitude-Behavioral Intention" Gap. J. Agric. Environ. Ethics 2006, 19, 169-194. [CrossRef]

34. Gilg, A.; Barr, S.; Ford, N. Green consumption or sustainable lifestyles? Identifying the sustainable consumer. Futures 2005, 37, 481-504. [CrossRef]

35. Van Liere, K.D.; Dunlap, R.E. Environmental Concern: Does It Make a Difference How It's Measured? Environ. Behav. 1981, 13, 651-676. [CrossRef]

36. Peattie, K. Golden goose or wild goose, the hunt for the green consumer. Bus. Strateg. Environ. 2001, 10, 187-199. [CrossRef]

37. Kollmuss, A.; Agyeman, J. Mind the gap: Why do people act environmentally and what are the barriers to pro-environmental behavior? Environ. Educ. Res. 2002, 8, 239-260. [CrossRef]

38. Ouellette, J.A.; Wood, W. Habit and Intention in Everyday Life: The Multiple Processes by Which Past Behavior Predicts Future Behavior. Psychol. Bull. 1998, 124, 54-74. [CrossRef]

39. Carrington, M.J.; Neville, B.A.; Whitwell, G.J. Why ethical consumers don't walk their talk: Towards a framework for understanding the gap between the ethical purchase intentions and actual buying behaviour of ethically minded consumers. J. Bus. Ethics 2010, 97, 139-158. [CrossRef]

40. Blumenschein, K.; Blomquist, G.C.; Johannesson, M.; Horn, N.; Blumenschein, K.; Blomquist, G.C.; Johannesson, M.; Horn, N. Eliciting Willingness to Pay without Bias: Evidence from a Field Experiment Published by: Wiley on behalf of the Royal Economic Society Stable. Econ. J. 2008, 118, 114-137. [CrossRef]

41. Lusk, J.L. Effects of cheap talk on consumer willingness-to-pay for golden rice. Am. J. Agric. Econ. 2003, 85, 840-856. [CrossRef]

42. Sanctuary, M.; Friberg, R. What's holding it back? A study in organic retail coffee purchases. In Essays on Trade and Environment; Department of Economics, Stockholm University: Stockholm, Sweden, 2013; pp. 85-110.

43. Aertsens, J.; Verbeke, W.; Mondelaers, K.; van Huylenbroeck, G. Personal determinants of organic food consumption: A review. Br. Food J. 2009, 111, 1140-1167.

44. Thøgersen, J. Consumer behaviour and the environment: Which role for information? In Environment, Information and Consumer Behaviour; Edward Elgar: Cheltenham, UK, 2005; pp. 51-63.

45. Hines, J.; Hungerford, H.; Tomera, A. Analysis and synthesis of research on responsible environmental behavior: A meta-analysis. J. Environ. Educ. 1987, 18, 1-8. [CrossRef]

46. Stern, P. Information, incentives, and proenvironmental consumer behavior. J. Consum. Policy 1999, 22, 461-478. [CrossRef]

47. Statistics Sweden. 2012. Available online: http://www.scb.se/en_/ (accessed on 1 September 2016).

48. Pieniak, Z.; Verbeke, W.; Olsen, S.O.; Hansen, K.B.; Brunsø, K. Health-related attitudes as a basis for segmenting European fish consumers. Food Policy 2010, 35, 448-455. [CrossRef]

49. Loo, R. A caveat on using single-item versus multiple-item scales. J. Manag. Psychol. 2001, 17, 68-75. [CrossRef] 
50. Wanous, J.P.; Reichers, A.E.; Hudy, M.J. Overall job satisfaction: How good are single-item measures? J. Appl. Psychol. 1997, 82, 247-252. [CrossRef] [PubMed]

51. Thøgersen, J. Psychological determinants of paying attention to eco-labels in purchase decisions: Model development and multinational validation. J. Consum. Policy 2000, 23, 285-313. [CrossRef]

52. Burnham, K.P.; Anderson, D.R.; Huyvaert, K.P. AIC model selection and multimodel inference in behavioral ecology: Some background, observations, and comparisons. Behav. Ecol. Sociobiol. 2011, 65, 23-35. [CrossRef]

53. Symonds, M.R.E.; Moussalli, A. A brief guide to model selection, multimodel inference and model averaging in behavioural ecology using Akaike's information criterion. Behav. Ecol. Sociobiol. 2010, 65, 13-21. [CrossRef]

54. Burnham, K.; Anderson, D. Model Selection and Multimodel Inference, 2nd ed.; Springer-Verlag: New York, NY, USA, 2002.

55. FAO. Salmo Salar. Available online: http://www.fao.org/fishery/culturedspecies/Salmo_salar/en (accessed on 9 April 2014).

56. Rose, J.; Bricker, S.; Tedesco, M.A.; Wikfors, G. A role for shellfish aquaculture in coastal nitrogen management. Environ. Sci. Technol. 2014, 48, 2519-2525. [CrossRef] [PubMed]

57. Primavera, J.H. Overcoming the impacts of aquaculture on the coastal zone. Ocean Coast. Manag. 2006, 49, 531-545. [CrossRef]

58. Little, C.D.; Bush, S.R.; Belton, B.; Thanh Phuong, N.; Young, J.A.; Murray, F.J. Whitefish wars: Pangasius, politics and consumer confusion in Europe. Mar. Policy 2012, 36, 738-745. [CrossRef]

59. Swedish National Food Agency. Guidance on Seafood Consumption. Available online: http://www. livsmedelsverket.se/livsmedel-och-innehall/oonskade-amnen/miljogifter/dioxiner-och-pcb/ (accessed on 22 July 2016). (In Swedish)

60. WWF Fish Guide Sweden. 2014. Available online: http://www.wwf.se/press/pressrum/ pressmeddelanden/1550885-ww-fs-fiskguide-2014-rtt-ljus-fr-vstkustrka-och-stenbitsrom (accessed on 9 April 2014). (In Swedish)

61. FAO. Pandalus Borealis. Available online: http://www.fao.org/fishery/species/3425/en (accessed on 9 April 2014).

62. FAO. Fishing Area 27. Available online: http://www.fao.org/fishery/area/Area27/en. (accessed on 9 April 2014).

63. Onozaka, Y.; Uchida, H.; Morita, T.; Managi, S. Uninformed or Uninterested? Surveys Examine Japanese Consumers' Interest in Sustainable Seafood. Available online: http://pdf.gaalliance.org/pdf/GAAOnozaka-July10.pdf (accessed on 1 September 2016).

64. Verbeke, W.; Sioen, I.; Brunsø, K.; de Henauw, S.; van Camp, J. Consumer perception versus scientific evidence of farmed and wild fish: Exploratory insights from Belgium. Aquac. Int. 2007, 15, 121-136. [CrossRef]

65. MSC Undersökning om Attityder Och Kännedom. 2012. Available online: https://www.msc.org/ dokument/informationsmaterial/konsumentundersokning/kondumentundersokning-2014/view (accessed on 12 November 2014). (In Swedish)

66. Marine Stewardship Council. The Increasing Appetite for Sustainable Seafood. Available online: http:/ / www.slideshare.net/MSCecolabel/msc-2014?next_slideshow=1 (accessed on 12 November 2014).

67. Kalnikaitè, V.; Bird, J.; Rogers, Y. Decision-making in the aisles: Informing, overwhelming or nudging supermarket shoppers? Pers. Ubiquitous Comput. 2012, 17, 1247-1259. [CrossRef]

68. Gelcich, S.; Buckley, P.; Pinnegar, J.K.; Chilvers, J.; Lorenzoni, I.; Terry, G.; Guerrero, M.; Castilla, J.C.; Valdebenito, A.; Duarte, C.M. Public awareness, concerns, and priorities about anthropogenic impacts on marine environments. Proc. Natl. Acad. Sci. USA 2014, 111, 15042-15047. [CrossRef] [PubMed]

69. Oken, E.; Choi, A.L.; Karagas, M.R.; Mariën, K.; Rheinberger, C.M.; Schoeny, R.; Sunderland, E.; Korrick, S. Review Which Fish Should I Eat? Perspectives Influencing Fish Consumption Choices. Environ. Health Perspect. 2012, 120, 790-798. [CrossRef] [PubMed]

70. Grunert, K.G.; Hieke, S.; Wills, J. Sustainability labels on food products: Consumer motivation, understanding and use. Food Policy 2014, 44, 177-189. [CrossRef]

71. Diamantopoulos, A.; Schlegelmilch, B.B.; Sinkovics, R.R.; Bohlen, G.M. Can socio-demographics still play a role in profiling green consumers? A review of the evidence and an empirical investigation. J. Bus. Res. 2003, 56, 465-480. [CrossRef] 
72. Polymeros, K.; Kaimakoudi, E.; Mitsoura, A.; Nikouli, E.; Mente, E. The Determinants of Consumption for Organic Aquaculture Products-Evidence From Greece. Aquac. Econ. Manag. 2014, 18, 45-59. [CrossRef]

73. Vidgen, H.; Gallegos, D. What Is Food Literacy and Does It Influence What We Eat: A Study of Australian Food Experts; Queensland University of Technology: Brisbane, Australian, 2011.

74. Fraj-Andrés, E.; Martínez-Salinas, E. Impact of Environmental Knowledge on Ecological Consumer Behaviour. J. Int. Consum. Mark. 2008, 19, 73-102. [CrossRef]

75. Brosdahl, D.J.C.; Carpenter, J.M. Consumer Knowledge of the Environmental Impacts of Textile and Apparel Production, Concern for the Environment, and Environmentally Friendly Consumption Behavior. J. Text. Appar. Technol. Manag. 2010, 6, 1-9.

76. Zaichkowsky, J.L. Measuring the Involvement Construct. J. Consum. Res. 1985, 12, 341-352. [CrossRef]

77. Nielsen, S. ScanTrack. Eco-Labeled Share of the Sales Value of Frozen Seafood from Swedish Retailers, August 2013-August 2014 (52 Weeks), 2014. Unpublished work, 2014.

78. Kjelstrup, L. (Norges Sjömatsråd, Stockholm, Sweden). Personal communication, 2013.

(C) 2016 by the authors; licensee MDPI, Basel, Switzerland. This article is an open access article distributed under the terms and conditions of the Creative Commons Attribution (CC-BY) license (http://creativecommons.org/licenses/by/4.0/). 